\title{
$\mathrm{SF}_{6}$ ガス中微小放電を伴った ギャップの絶縁破壊
}

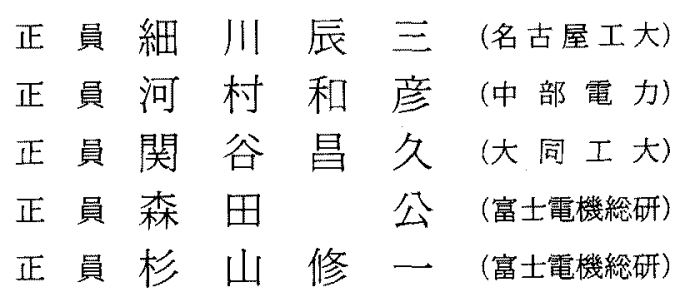

\section{Breakdown Mechanism of a Gap with Small Arc Current in $\mathrm{SF}_{6}$ Gas}

Tatuzo Hosokawa, Member (Nagoya Institute of Technology), Kazuhiko Kwamura, Member (Chubu Electric Power CO., Inc.), Yoshihisa Sekiya, Member(Daido Institute of Technology), Tadashi Morita, Member(Fuji Electric Corporated R\&D Ltd.), Shuichi Sugiyama, Member (Fuji Electric Corporated R\&D Ltd.)

The model experimental apparatus for poor contact portion of the gas-insulated switchgear is assumed to a rod-to-plane gap with small arc current in $\mathrm{SF}_{6}$. The breakdown voltage in a gap at gas pressure of $0.1 \mathrm{MPa}$ and small arc current of $1 \mathrm{~A}$ have been studied.

The effect of the small arc current on the breakdown in the gap was investigated experimentally, and the breakdown mechanism in the gap was studied. Also gas temperature and density were calculated by fluid analysis.

It was cleared that the small arc current played an important role on the breakdown in the rod -to-plane gap, and the hot gas produced by an arc was a principal factor of reduction of the breakdown voltage. The decomposition products produced by the arc were absorbed in an activated almina effectively, and the breakdown voltage in the gap increased by setting the activated almina in a chamber.

The time history of the breakdown voltage was characterized by six domains, and these breakdown mechanisms were explained by the development of the arc. The schematic diagram of the breakdown mechanism was proposed by the authors.

キーワード：ガス絶縁開閉装置，六フッ化イオウガス，絶縁低下，アーク

\section{1.まえがき}

六フッ化イオウガス（以下， $\mathrm{SF}_{6}$ と記す）は，絶縁 破壊強度が空気の 2.5 倍と高いうえ, 絶緑油に比べて 軽量で, 化学的にも安定なことから, 近年絶緑油に代 わって高電圧の絶縁媒体として種々の電力機器に使用 されている。特にガス絶縁開閉装置 (GIS) は，大幅 なスペース縮小化を目指した発変電所用開閉装置とし
て, 積極的に採用されている。 他方，近年エレクトロニクスの発展と相まって，ワ ードプロセッサやコンピュータなどエレクトロニクス の応用機器の普及が急速に進み, 電力系統の瞬時の停 電でもこれに与える影響が大きく，電力の安定供給の 重要性が增している。

このような観点から, 著者らは電力系統におけるガ ス絶縁開閉装置の開閉接点部の接触不良に起因した接 
点部と容器壁間の絶縁破壊の解明とその予知技術の開 発を目的に，模擬実験装置を用い $0.1 \sim 0.5 \mathrm{MPa}(1$ $\sim 5$ 気压）の $\mathrm{SF}_{6}$ 中接触不良を模擬した $1 \sim 3.6 \mathrm{~A} の$ アーク放電が模擬接触部と模擬器壁間の絶縁破壊に与 える影響について研究を進めている(1)〜(3)。

ところで，0.1〜0.2 MPa の $\mathrm{SF}_{6}$ 中で模擬接触部に 1 2Aの微小放電電流子流すと, 微小放電 (以後, アークと呼ぶ）と模擬器壁間の破壊電圧は，アーク発 生 (以後, アーク点弧と呼ぶ) 初期で異常低下を起こ すが，アークを継続させると数分後上昇して，アータ を伴わない場合より低いが絶縁を回復する。しかし， 更にアークを継続させると破㗒電纴は再び低下しはじ め, 特に模擬器壁をアーク点弧用電極の真上に配置し た場合には，ギャップの長さが $30 \mathrm{~mm}$ 以下で破壊電 圧は 80\% 90\%低下した。またこの低下は，微小ギ ヤップ長，アーク電流，気圧などによって異なるが， その主な要因はアークの微小ギャップ外への噴出によ る高温気体 (Hot gas) ${ }^{(4) ~(11)}$ の上昇気流（浮力）に起 因していることは既に報告した ${ }^{(2)(3)}$ 。しかし，アータ 点弧直後に現れる破壤電圧の異常低下については不明 な点が多い。

本研究は, アーク点弧直後に現れる破壊電圧の異常 低下ならびに経時変化の解明を目的に，0.1 MPaの $\mathrm{SF}_{6}$ 中で模擬接触部に $1 \mathrm{~A}$ の電流を流し, 破壊電压の 低下に及ぼす接触部材料ならびに微小ギャップ長の影 響を電気的および光学的手法を用いて調べ，その破壊 幾構の解明を行った。その結果, $\mathrm{SF}_{6}$ 中アータを伴っ たギャップで観測される破壊電圧の異常低下ならびに 経時変化について検討し, その破壊機構を明らかにし to

本論文はそれらの結果をまとめたもので， $\mathrm{SF}_{6}$ 中ア 一クを伴ったギャップの破塤特性を述心゙，更に破壊の 経時変化に対する模式図を示し，その破壊機構を提案 している。

\section{2. 実験装置と実験方法}

アークが模擬開閉装置接点部と器壁間の絶縁破壊に 及ぼす影響を調べるための模擬実験装置の回路図を図 1 に示す。本研究では，接点部の接触不良の模擬とし て，図に示すような 2 本の棒電極を対向させ，電極間 隔 $0.3 \sim 1.1 \mathrm{~mm}$ の微小ギャップを形成させた。なお， 実用の開閒装置の接点部は主に銅製であることから， 本実験に抽しも電極材料の影響を調へたとき以外 は，その先端をほほ平面状とした直径 $10 \mathrm{~mm}$ 一対の 銅製棒電極を用いた。また，開閉装置の容器壁はステ

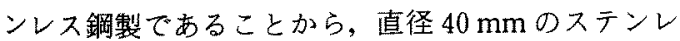

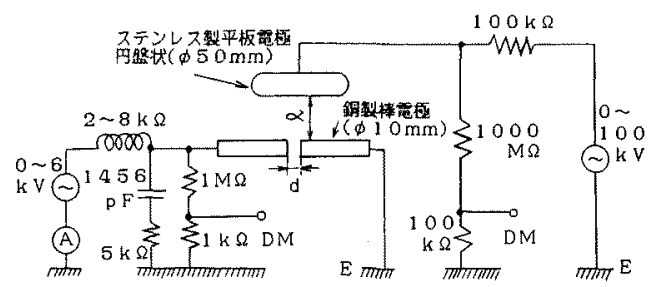

图 1 実験回路

Fig. 1. Experimental Circuit.

ス鋼製ロゴウスキー形電極で器壁を模擬した。

銅製棒電極は，一度実験を行うと消耗が激しく，加 つ表面に被模が生ずるので，実験ごとに鉄ヤスりで被 膜を除去した後先端を平面状に整形し, その後, 更に サンドペーパとピカールで表面を鏡面状に研磨した。 また, 容器壁を模擬したロゴウスキー形電極（以後, 前報 ${ }^{(2)(3)}$ 同様ディスクと呼ぶ）も一度実験を行うと幾 分污れたので，実験ごとに表面をアルコールを含んだ ガーゼで拭いた。 $\mathrm{SF}_{6}$ の充てんは, 奉験容器内を油回 転ポンプで7 Pa以下になるまで排気した後, $\mathrm{SF}_{6}$ を 所定の压力まで充てんした。なお，圧力の影響字調べ たとき以外は, 圧力はすべて $0.1 \mathrm{MPa} て ゙$ 実験を行っ ている。

微小放電は, $\mathrm{AC} 200 \mathrm{~V}, 60 \mathrm{~Hz}$ の商用周波電源を スライダック, 200:6,000の変圧器を経て 6,000 V K 昇圧し，これを $0.3 \sim 1.1 \mathrm{~mm}$ の微小放電ギャップに 印加して発生させた。放電電圧は抵抗分圧 $(1 \mathrm{M} \Omega: 1$ $\mathrm{k} \Omega)$ で，放電電流は低抵抗 $(1 \Omega$ あるいは $100 \Omega)$ の電 压降下をオシロスコープ（岩崎通信機製 SS-5705）と 電流計で測定した。また，回路中の $L, C, R$ は, 電 力送電線の分布インダクタンスと分布容量を模擬した インダタタンスと容量, 電流制限のためのインダクタ ンス，放電雑音吸取のための容量と抵抗などを等価的 に含んでいる。

棒電極とディスク間に絶縁破壊を起こさせるため, ディスクは， $\mathrm{AC} 200 \mathrm{~V}, 60 \mathrm{~Hz}$ の商用周波電源をス ライダックを経て $50 \mathrm{kV}$ まで昇圧できる変圧器に接 続されて抢り，破壊電圧は1叧間隔で測定した。また その電压は，抵抗分圧 $(1,000 \mathrm{M} \Omega: 10 \mathrm{k} \Omega)$ で分圧し, その出力をディジタルマルチメータ（岩崎通信機製 SC-7401）に入力し実効值で表示している。なお，本 実験では，棒電極とディスクとの間隔を主ギャップ長 $l$, その全路破壊電仕を破壇電圧 $V_{s}$ と呼び，lはす心゙ て $10 \mathrm{~mm} て ゙$ 行っている。また, 微小ギャップ長 $d$ は アーク熱による棒電極の熱膨張と蒸発消耗のため常に 変わるが, ギャップの長さがほぼ一定の值に達すると 
$V_{s}$ の低下が始まるため ${ }^{(2)}$ ，初期設定值からその值に 達するまでの時間が破壊予知には重要な時間である。 このようなことから，本研究ては実験設備を考慮し， 微小ギャップ長 $d$ の影響を調べた場合以外流，実験 は初期設定值 $d=0.5 \mathrm{~mm}$ で行っている。

\section{3. 実験結果}

〈3・1〉破壊電圧の経時䆦化 $\mathrm{SF}_{6}$ 中アークを伴 った主ギャップの破壊電圧 $V_{s}$ は，アークの継続時間 によって変化する。気压 $p \leqq 0.2 \mathrm{MPa}$ ，主ギャップ長 $l \leqq 20 \mathrm{~mm}$ の実験範囲内では， $V_{s}$ はアーク点弧直後 の初期（以後初期特性と㭔ぶ）でアークを伴わない場 合に比べ $50 \%$ 以上の大幅な低下を示すが，その後時 間の経過に伴って上昇しはじめ，ギャップ条件によっ て幾分異なるが数分後に最大值 (以後, 前報(2)(3) 同様 I 領域と呼ぶ）を示した後再び大幅な低下（以後， 前報 ${ }^{(2)(3)}$ 同様II 領域と呼子゙) を示す ${ }^{(2)(3) 。 ~}$

図 2 はその典型的一例で，アーク点弧用電極として 銅を用い, その微小ギャップ長 $d=0.5 \mathrm{~mm}$ (初期設

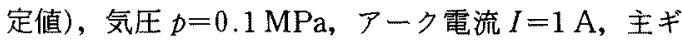
ヤップ長 $l=10 \mathrm{~mm}$ (本論文では, 以後, 特に断らな い限りこの条件で実験を行っている)における主ギャ ップの破壊電圧 $V_{s}$ とアーク継続時間 $t$ との関係をデ ィスクがアーク電極の真上（以後，上側と記す）と真 下（以後，下側と記す）に配置した場合について示し ている。図において，Vsはアーク点弧直後の初期に

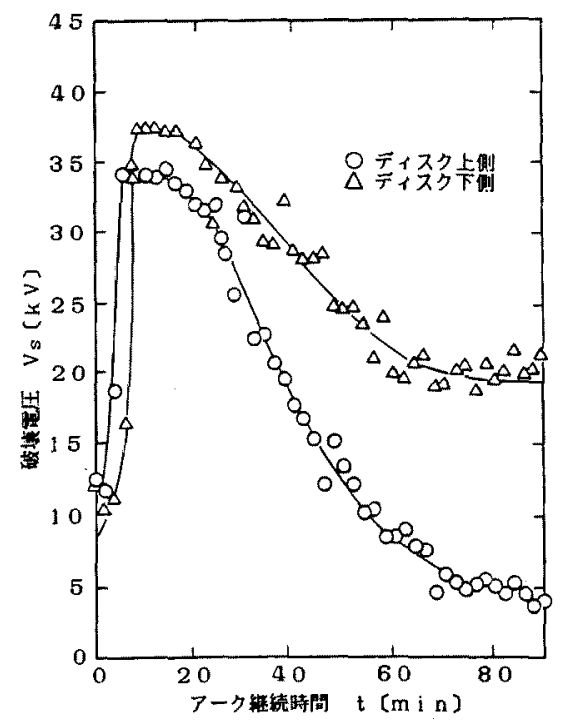

図 2 破壊電压とアーク継続時間の関係

Fig. 2. Breakdown voltage as a function of time.
おいて低いが，時間の経過に伴って上昇し，上側配置 ではほほ 10 分後に最大值を示し, 更にほほ 10 分間 I 領域を示した後時間と共に再び低下した。またこの特 性はディスクの配置によって異なり，下側配置のVs は上側配置に比へて高くかつI領域は幾分短かった。

このように，V $V_{s}$ はディスクの配置によって幾分異 なり，後でも述べるように，一般にディスクが下側配 置の $V_{s}$ は上側配置に比べて高い。しかし特性の傾向 は類似しているので，以後は上側配置あるいは下側配 置の場合のみについて述べる。

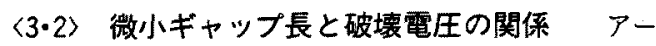
クを伴ったギャップの $V_{s}$ は，伴わない場合に比べて 大幅に低下するが， $V_{s}$ の低下はアーク長に関係する。

図 3 は，ディスクを上側に配置し，アーク点弧後 15 分間の $V_{s}$ と $t$ の関係を $d$ (初期設定值) をパラメ 一タとして表しており， $d=0.2 \sim 0.5 \mathrm{~mm}$ を(a)図 に, $d=0.5 \sim 1.1 \mathrm{~mm}$ を(b)図にそれぞれ示す。こ れらの図から， $d \geqq 0.3 \mathrm{~mm}$ でアークが継続し，一般 に $d$ (初期設定值) が增すに伴って初期特性の継続時 間が增し， $V_{s}$ 上昇特性から I 領域への移行は遅れる ことがわかる。また $d \geqq 0.5 \mathrm{~mm}$ では， $V_{s}$ の上舁特 性で $V_{s}$ がばらつきdの影響が認められなかったが，

I 領域では $d$ の增加に伴って $V_{s}$ は低下する傾向を示 した。なお， $d=0.2 \mathrm{~mm}$ では, アーク点弧 1 分後に 最大值に達した後低下しはじめたが，2 分後にアーク が休止し $V_{s}$ は急上界した。これは，後でも述べるよ うに，アークによる棒電極の熱膨張て銅の対向電極が 接触し，アークが消滅したことによる。この $d=0.2$

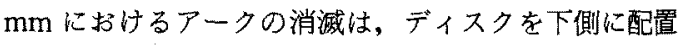
した場合にも同様な特性が得られた。更に前にも述べ たように，一般に平板電極が上側配置の $V_{s}$ は，下側 配置より低く，また初期特性に続く $V_{s}$ の上昇は，下 側配置では上側配置に比べ遅れる傾向を示した。

このように， $V_{s}$ の低下は $d$ にも関係するので, 次 に $V_{s}$ および $d$ と $t$ の関係を図 4 に示す。

図 4 㹥微小ギャップ電極として銅棒を用い $d=0.5$ $\mathrm{mm}$ (初期設定)，ディスクを上側に配置した場合の 結果の一例を示す。図から，Vsはアーク点弧後初期 特性とI 領域を経て 60 分後にII領域へ移行している。 他方, $d$ は初期特性で注隇少し， $V_{s}$ の最大值て最小 值を示した後増加しはじめ, $d \fallingdotseq 1.3 \mathrm{~mm}$ でII領域へ 移行している。なお， $d$ はアーク点弧後 6 分で約 $0.23 \mathrm{~mm}$ まで滅少したが，これはアークに起因した 棒電極の熱膨張でギャップがほほ $0.27 \mathrm{~mm}$ 短縮した ことを意味している。

これらの結果から， $V_{s}$ の上昇には $d$ の減少も関係 


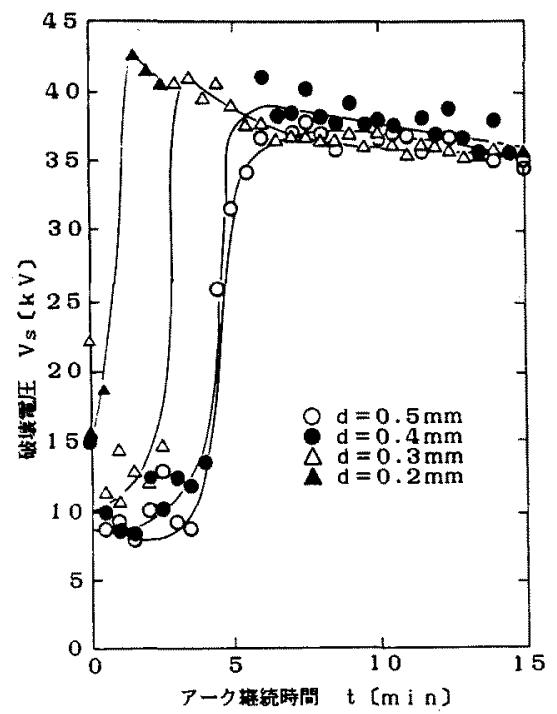

(a)

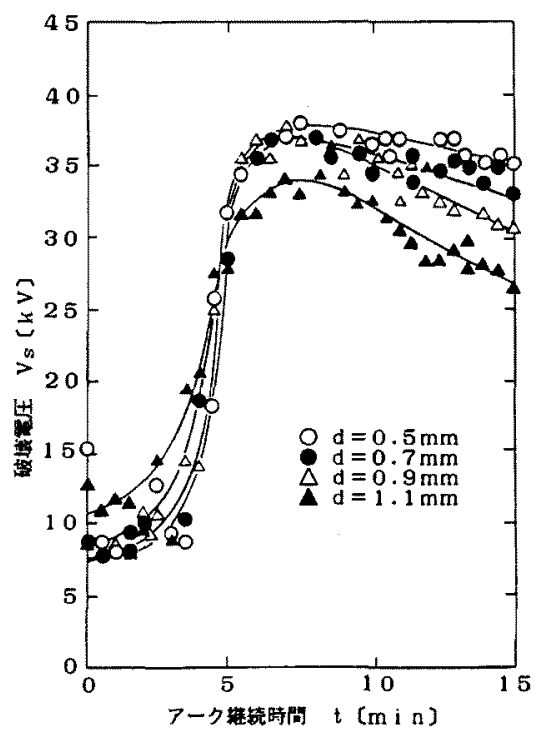

(b)

図 3 破壊電圧とアーク継続時間の関係 (ディスク上側)

Fig. 3. Breakdown voltage as a function of time with arc gap length as a parameter (disk arranged abovo the arc).

しており，アーク点弧直後の初期特性からの $V_{s}$ の上 昇には $d$ の減少も重要な役割を演していることがわ 加る。

この特性を更に確かめるために，アーク電極材料と して同一形状の W $(70 \%)-\mathrm{Cu}(30 \%)$ ，炭素，Alにつ

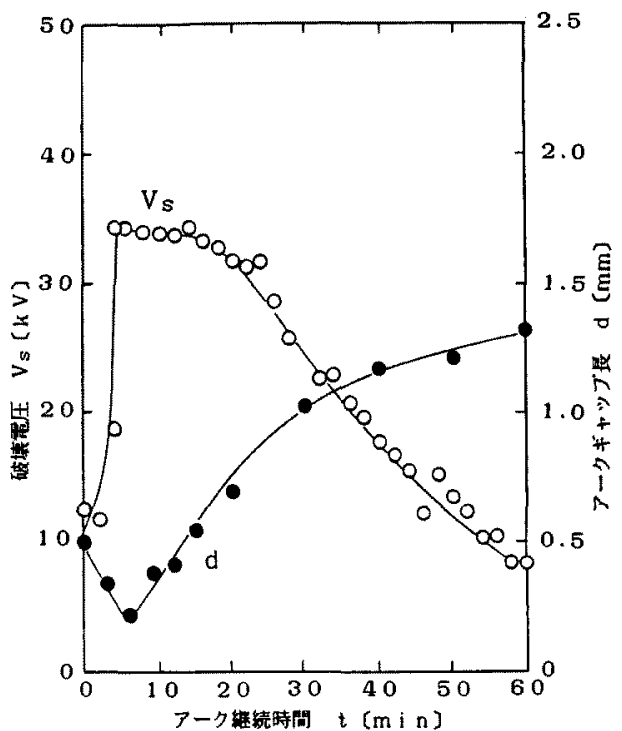

図 4 破壊電圧, アークギャップ長とアーク 継続時間の関係（ディスク上側）

Fig. 4. Both breakdown voltage and arc gap length as a function of time (disk arranged above the arc).

いて検討した。図 5 はディスクを上側に配置した場合 の結果で，(a)図はW-Cu，（b)図は炭素，(c)図 は $\mathrm{Al}$ の特性をそれぞれ示す。W-Cu電極では，熱膨 張, 消耗が小さいため, 初期特性から最大值へ達する までの時間も長く，かつII領域への移行も長時間必要 であることがわかる。他方炭素電極では，アークによ って電極は消耗するのみで, 従って $V_{s}$ には初期特性 と I 領域は観測されなかった。更に， $\mathrm{Al}$ 電極では， I 領域とII領域の特性は観測されたが，初期特性は観 测されなかった。なお，図より明らかなように，W$\mathrm{Cu}$ 電極と $\mathrm{Al}$ 電極では, 測定值がばらつき $V_{s}$ に不整 を伴った。

これらの結果から，初期特性からの $V_{s}$ の上昇に は，dの減少も重要な役割を演じていることが確認さ れる。更に重要なことは，Al電極では初期特性が観 測されなかったことから，初期特性は電極表面の清浄 さに関係していることがわかる。つまり，これはAl は空気中で酸化皮膜が生じやすいことを考慮すれば， アークによって生成される分解化合物による電極表面 の絶縁物化が $V_{s}$ の上昇に最も重要な役割を演じてい ることを示唆している。

く3・3〉アークに起因した分解ガスの影響 前に も述べたように，微小放電を伴ったギャップの $V_{s}$ は 伴わない場合に比べて大幅な低下を示す。この原因の 


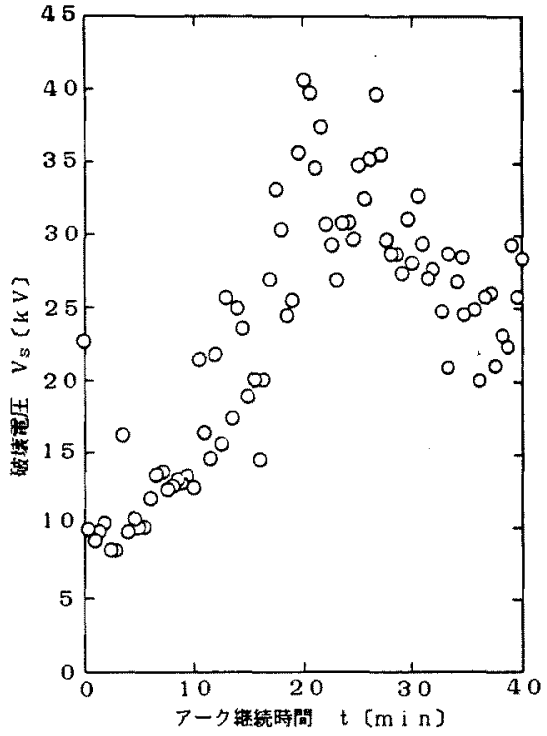

(a) $\mathrm{Cu}-\mathrm{W}$ 龟整

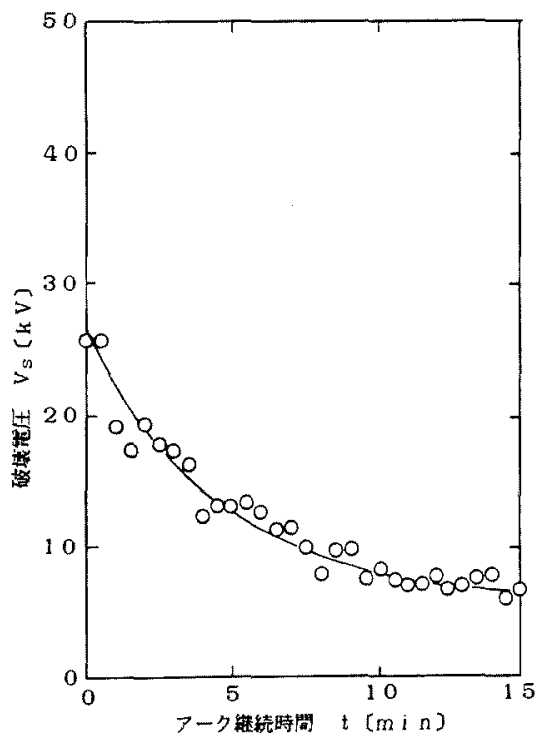

(b) 策素䡈再

一つとしてアークによる分解ガス ${ }^{(12)}$ の影響が考えら れるので，その影響を検泟するために実験容器内に分 解ガスを吸収する活性アルミナ(13) (以後, $\mathrm{Al}_{2} \mathrm{O}_{3}$ と記 す)を入れ， $V_{5}$ に敒す $\mathrm{Al}_{2} \mathrm{O}_{3}$ の影響について検討 Lた。

図 6 はディスクを上側に配置した場合の結果の一例 で， $\mathrm{Al}_{2} \mathrm{O}_{3}$ を入れた場合と入れない場合について比較 している。図から明らかなように， $\mathrm{Al}_{2} \mathrm{O}_{3}$ を入れても 初期特性とII領域の特性では影響がほとんど認められ

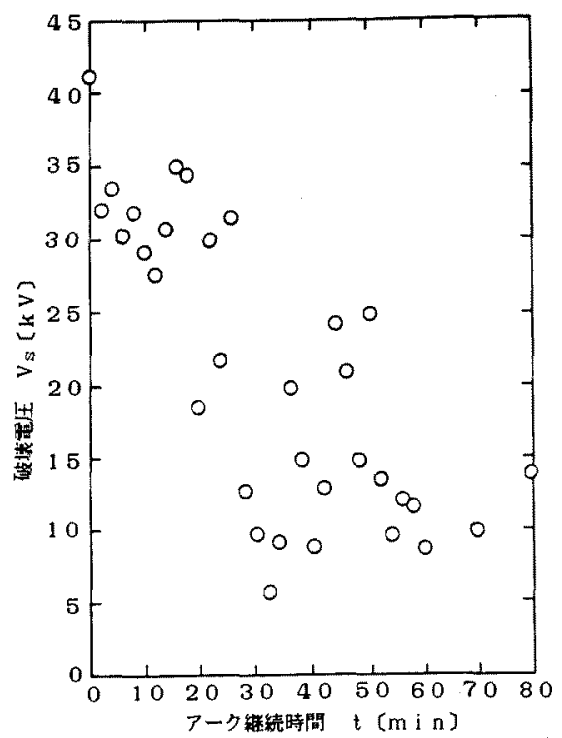

(c) A \& 需医

図 5 破壊電圧に及ぼす電極材料の影響 (ディスク上側)

Fig. 5. Effect of electrode material on the Breakdown voltage (disk arranged above the arc)

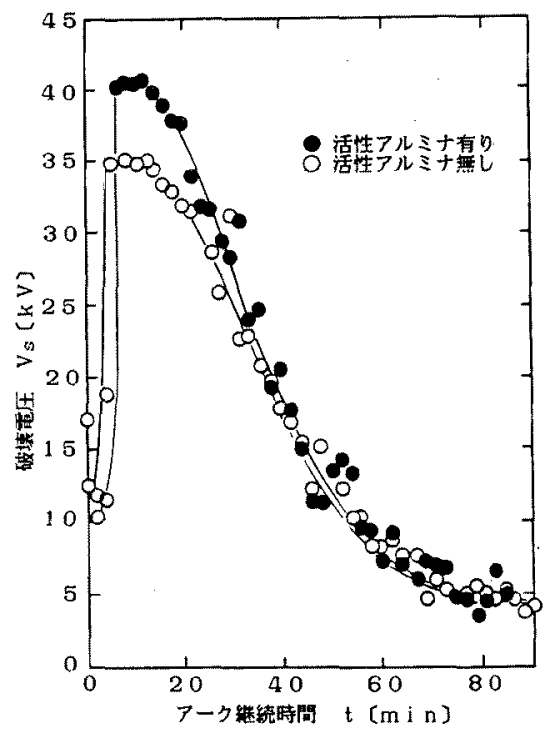

図 6 破壊電压に及ほすす活性アルミナの影響 Fig. 6. Effect of $\mathrm{Al}_{2} \mathrm{O}_{3}$ on the Breakdown voltage (Disk arranged above the arc).

ないが，I領域の特性には影響が現れ，特にディスク を上側に配置した場合の $V_{s}$ は， $\mathrm{Al}_{2} \mathrm{O}_{3}$ を入れること によってI 領域で約 $20 \%$ 上昇することがわかる。 


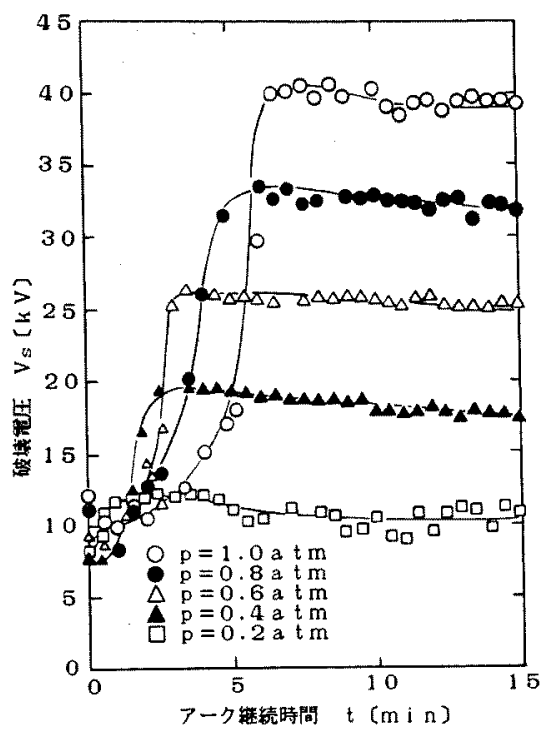

図 7 破壞電圧とアーク継続時間の関係

(ディスク下側, $p$ をバラメータ)

Fig. 7. Breakdown voltage as a function of time with pressure as a parameter (disk arranged under the arc).

〈3.4〉破壊電圧と圧力の関係 図 7 はディスク を下側に配置した場合の $V_{s}$ と $t$ の関係を $p$ をパラメ 一タとして示している。図から， $p$ を增すと初期特性 およびI 領域の $V_{s}$ 恃上昇し, かつ初期特性からI領 域への移行は遅れることがわかる。

\section{4. 考察}

\section{〈4・1〉 アーク放電点弧による破壊電圧低下の要因}

アークを伴ったギャップの絶縁破壤では, アーク点 弧の初期と長時間経過後に $V_{s}$ の異常低下が観測され た。破壊電圧低下の要因として，（1）高温気体の影 響，(2) 電離気体の影響，(3) 分解ガスの影響，(4) ガス圧力の影響, などが考えられる。ここでは, これ らについて考察する。

（1）高温気体の影響破壊電圧低下には，高温 気体による上昇気流と気体密度の低下が重要な役割を 演じるものと考えられる ${ }^{(3)}$ 。ここでも同じ計算方法 ${ }^{(3)}$ で気流の計算を試みた。図 8 は，図 3 と同じ実駼条件 $(p=0.1 \mathrm{MPa}, I=1 \mathrm{~A}, l=10 \mathrm{~mm})$ でアーク点弧 100 $\mathrm{ms}$ 後における気流の速度ベクトル図をディスクを上 側に配置した場合〔( a )図〕と下側に配置した場合 ((b)図)について示している。これらの図加ら,ディス クを下側へ配置した場合でも，ディスクとアーク間に は，上向きの気流が存在することがわかる。な抬後て

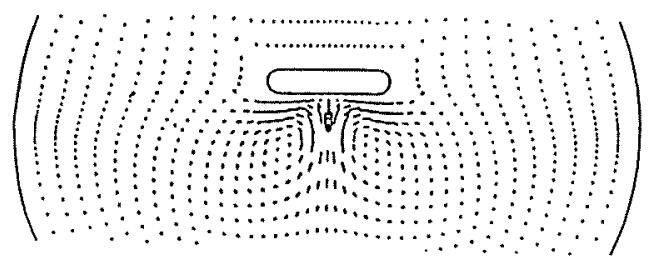

(a) ゙゙ィスク上㖥大流速 $0.12 \mathrm{~m} / \mathrm{s}$

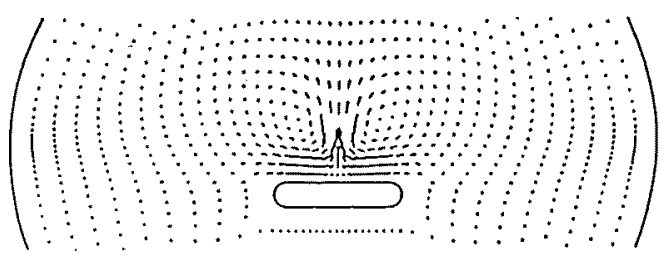

(b) ティスク上側 量大流速 $0.13 \mathrm{~m} / \mathrm{s}$

図 8 気流計算によるアータ点弧 $100 \mathrm{~ms}$ 後 の速度べクトル図

Fig. 8. Velocity vectors at $100 \mathrm{~ms}$ after the arc ignition by fluid analysis.

も述べるように，ディスクを下側に配置した場合の $V_{s}$ が上側に配置した $V_{s}$ に比べて高く現れるのは， この上向き気流の影響と考えられる。また，これらの 結果を基に，アーク中心からディスク中心へ向かって $7 \mathrm{~mm}$ と $12 \mathrm{~mm}$ の位置に抬汀る気体の温度 $T$ および密 度 $\rho$ の時間変化を求めた結果を図 9 に示す。これら の図から明らかなように，アーク発弧後ほほ $100 \mathrm{~ms}$ で温度は最大值に，密度は最小值にそれぞれ達するこ とがわかる。更に，ディスクが上側配置のほうが下側 配置に比べて温度㛎高く, 密度は低くなることもわか る。

次に，これらの結果を考慮すれば，アークを長時間 点弧させた場合にアーク弧が大きく上向きに膨らむ が,この現象は, 長時間点弧による電極の消耗でギヤ ップ長が増加し，更に，上昇気流がアークを上方に押 し上げるためと考えられる。従って，平板電極を上側 に配置した場合， $V_{s}$ が著しく低下するのは，上昇気 流で平板䉓極とアークの弧の先施部との距離が狭まる ためと解釈される。

またアアークの点弧によって陰極の $\mathrm{Cu}$ が蒸発する が，このときの蒸気温度は少なくともCuの沸点 (2,853 K)であることは明らかである。従って，高温 気体内部では, $E / N$ 分布 $(E:$ 電界, $N$ : 分子密度 $)$ の増大により， $\alpha$ 作用が増大して電子なだれの成長を 助け，破壊電圧を低下させていることも考光られる。

（2）電離気体の影響 アークの陽光柱（アーク 


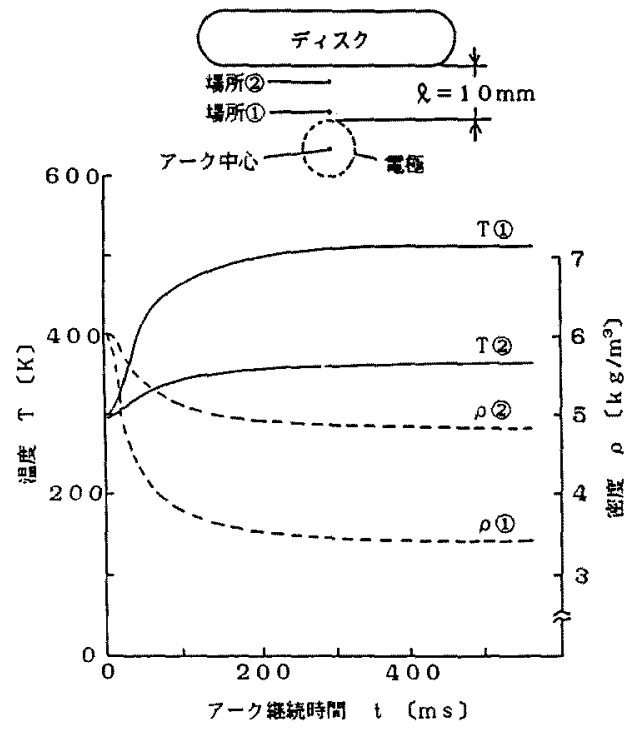

(a)ディク上侧

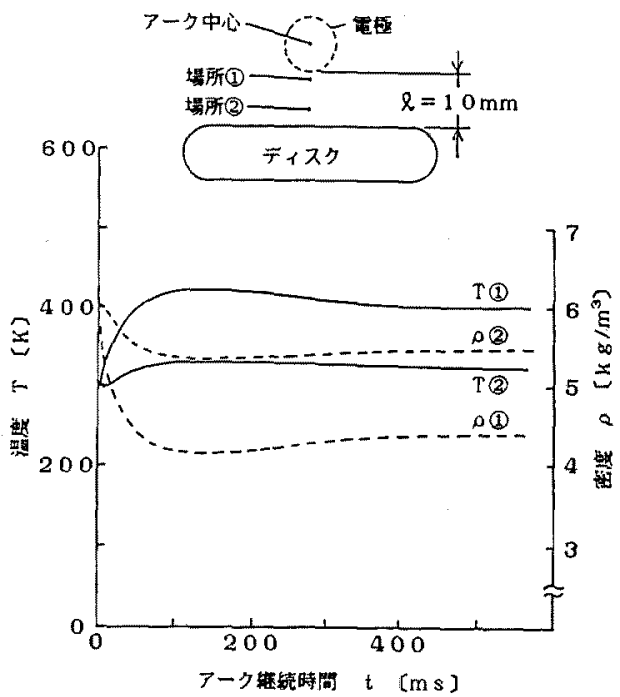

(b) ティスク下啃

图 9 気流計算による気体の温度と密度の 時間変化

Fig. 9. Time histories of both gas temperature and density calculated by fluid analysis.

柱）は電子と正イオンが同じ密度のいわゆるプラズマ 状態となっている。破壊電圧の低下の原因として，主 ギャップの破壊は棒電極が陰極の位相で生じることか ら, 微小放電アークのプラズマ中の正イオンによる $\gamma_{i}$ 作用（正イオンの陰極への衝突による二次電子放
出）や，フラズマの発光からの紫外線放射による $\gamma_{p}$ 作用の影響なども考えられる(本論文ではこれらを総 称して等価的 $\gamma$ 作用と呼ぶ。また，プラズマの棒一 平板電極間への㹡散による $E / N$ 分布の增大は電子な だれの成長を助けることから，これも破壊電圧低下の 原因亡考えられる。

(3) アークにより生成する化合物および分解がス による影響アーク放電により， $\mathrm{SF}_{6}$ が $\mathrm{Cu}$ との反 応で分解されて化合物を生成し，これが棒電極表面に 付着する。この場合，生成される化合物は次の反応式 で示される(12)(14) (16)。

$$
\begin{aligned}
& \mathrm{SF}_{6}+\mathrm{Cu} \longrightarrow \mathrm{SF}_{4}+\mathrm{CuF}_{2} \\
& \mathrm{SF}_{4}+\mathrm{Cu} \longrightarrow \mathrm{SF}_{2}+\mathrm{CuF}_{2} \\
& 2 \mathrm{SF}_{6}+5 \mathrm{Cu} \longrightarrow \mathrm{S}_{2} \mathrm{~F}_{2}+5 \mathrm{CuF}_{2} \\
& \mathrm{~S}_{2} \mathrm{~F}_{2}+2 \mathrm{Cu} \longrightarrow \mathrm{SF}_{2}+\mathrm{Cu}_{2} \mathrm{~S} \cdots
\end{aligned}
$$

上記(1) （4)式の反応により生成する化合物は,

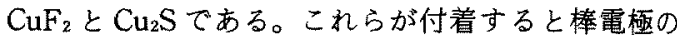
電子放出作用 (等洒的 $\gamma$ 作用) する。アーク点弧直後の初期特性加ら $V_{s}$ が上昇する I 領域への移行はこのためと解釈されるが, その速さ は，後でも述べるように，叧解化合物の棒電極先端を 覆う速さに関係する。

また，実験容器内に水分が混入している場合には， $\mathrm{SF}_{6}$ は水分とも反応する。この場合は次の反応式で示 される(12) 〜(19)。

$$
\begin{aligned}
& \mathrm{SF}_{4}+\mathrm{H}_{2} \mathrm{O} \longrightarrow \mathrm{SOF}_{2}+2 \mathrm{HF} \\
& \mathrm{S}_{2} \mathrm{~F}_{2}+\mathrm{H}_{2} \mathrm{O} \longrightarrow \mathrm{SOF}_{2}+\mathrm{H}_{2} \mathrm{~S} \\
& \mathrm{SOF}_{2}+\mathrm{H}_{2} \mathrm{O} \longrightarrow \mathrm{SO}_{2}+2 \mathrm{HF} \\
& \mathrm{CuF}_{2}+\mathrm{H}_{2} \mathrm{O} \longrightarrow \mathrm{CuOHF} \mathrm{HF} \\
& \mathrm{SO}_{2}+\mathrm{SF}_{6} \longrightarrow \mathrm{SO}_{2} \mathrm{~F}_{2}+\mathrm{SF}_{4} \cdots \cdots
\end{aligned}
$$

上記 ( 5 ) （ 9 ) 式の反応により生成する分解ガスは $\mathrm{HF}, \mathrm{H}_{2} \mathrm{~S}, \mathrm{SOF}_{2}, \mathrm{SO}_{2}$ 放よび $\mathrm{SO}_{2} \mathrm{~F}_{2}$ である。また， (1)〜(4)の反応により生成する分解ガスは $\mathrm{SF}_{4}$, $\mathrm{S}_{2} \mathrm{~F}_{2}, \mathrm{SF}_{2}$ でこれらの分解ガスは破壊電圧低下の要因 と考えられる。ところで, $\mathrm{Al}_{2} \mathrm{O}_{3}$ は上記分解ガスのう ち, $\mathrm{SO}_{2} \mathrm{~F}_{2}$ を除くすべての分解がスを吸収する作用が ある。従って、これらの分解ガスが $V_{s}$ 低下の要因で あるならば，実験容器内に $\mathrm{Al}_{2} \mathrm{O}_{3}$ をれればその影 響が現れるはずである。事実本研究に扔いても，図6 に示したように, $\mathrm{Al}_{2} \mathrm{O}_{3}$ を実験容器内に入れたところ I 領域の $V_{s}$ が $20 \%$ 程度上昇したことから, 分解が スは $V_{s}$ 低下の一要因であると結論される。な蚛，初 期特性と II 領域で $\mathrm{Al}_{2} \mathrm{O}_{3}$ の影響が顕著に現れなかっ たのは，これらの特性域では，分解がスの多量発生が $V_{s}$ の異常低不をもたらすために, $\mathrm{Al}_{2} \mathrm{O}_{3}$ の影響が観 
測されなかったものと解釈される。

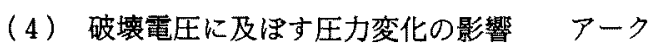
を伴ったギャップの $V_{s}$ は, 図 7 に示したように,ガ ス圧力が高いほどアーク点弧から $V_{s}$ 上舁までの時間 が長いことがわかる。これは, 分解ガスで生成される 化合物 $\mathrm{CuF}_{2}$ と $\mathrm{CuS}$ の生成の速さに関係し, 一般に 圧力が低下すると放電路が拡散して広まることから， 分解ガスで生成される化合物が電極を覆う速さは, 同 一電極配置では圧力が低いほど速いためと解釈され る。他方, 同じ圧力ならば, 図示していないが, 放電路 の広がりは変わらないことからアアーク電極の大きさ (半径)を減少させた場合にも同様な特性が得られる。

〈4・2〉破壊電圧低下の機構 アークを伴ったギ ヤップの絶縁低下の要因としては, 前節で述べたよう に, (1) 高温気体の影響, (2) 電離気体の影響, (3) 分解ガスの影響, (4)ガス圧力の影響, などが考えら れ，ディスク電極が上側配置の場合にはこれらの要因 の相乗効果によって $V_{s}$ は異常に低下するが，下側配 置の場合は気流が逆向きの分だけ上昇するものと解釈 される。

ここでは，これらの要因を考慮しながら， $V_{s}$ の経 時変化について考察する。

図10 は $\mathrm{SF}_{6}$ 中アークを伴ったギャップの絶縁低下 の経時変化を模式的に示したもので, その破壊機構と して次のような機構を提案したい。

（1）初期特性域 アーク点弧に伴う棒電極表面 の温度上昇による等価的 $\gamma$ 作用の急上昇 ${ }^{(20)}$ ならびに 電極付近の気体密度の低下に伴い $V_{s}$ が異常低下する

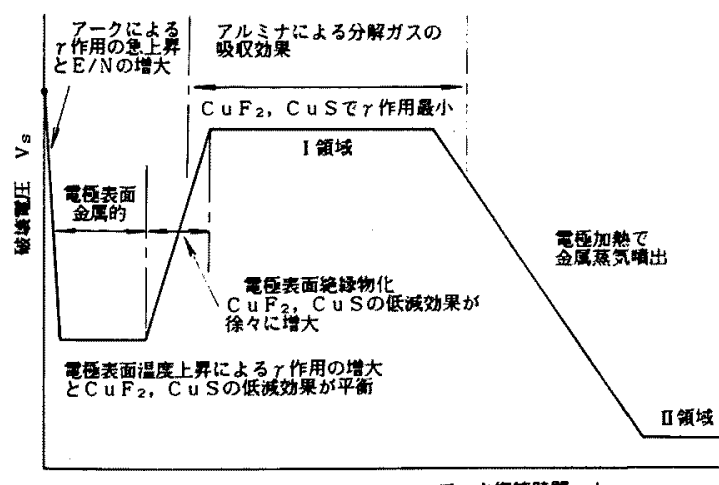

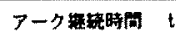

図 10 破壊電圧とアーク継続時間の関係に おりる破壊機構の模式図

Fig. 10. Schematic diagram of breakdown mechanism as a function of time in the rodto-plane gap with small arc current (disk arranged above the arc).

電学論 $B, 111$ 巻 3 号, 平成 3 年
特性域。

（2） $V_{s}$ 上昇域 アーク熱に上る棒電極の線膨 張に伴い, 微小放電ギャップ長 $d$ が減少するとホッ トガスの熱量も低隇し，上昇気流速度が低下してアー クが伸張しがたくなること, ならびに分解ガス化合物 が棒電極表面へ付着し, 等価的 $\gamma$ 作用の低減に伴う $V_{s}$ 上昇域。

（3）I領域 分解ガス化合物による等価的 $\gamma$ 作用最小域。また,この特性域では,アルミナによる 分解ガス吸収効果で $V_{s}$ は上昇する。

（4） $V_{s}$ 低下域 アークによる加熱で棒電極温 度が沸点以上に上昇し, 溶融金属分子がジェットとな って電極外へ噴出して， $V_{s}$ が低下する特性域。

（5）II領域溶融金属分子の噴出が活発化し, 主ギャップの未電離空間が短縮して $V_{s}$ が大幅に低下 する特性域。

〈4・3〉実用器への適用性について 本研究は, 前にも述べたように,ガス絶緑開閉装置の開閉接点部 の接触不良に起因した接点部と容器壁間の絶緑破壞の 解明とその予知技術の開発を目的に，気圧 $0.1 \mathrm{MPa}$ (1 気圧), アーク電流 $1 \mathrm{~A}$, 主ギャップ長 $10 \mathrm{~mm}$ と 小規模な模擬実験装置で実験を行ったもので, 得られ た結果をそのまま奏用器へ適用されるものではない。 しかし, 著者らがこれまで行った気圧 $0.1 \sim 0.5$ $\mathrm{MPa}$, アーク電流 1 3.6 A, 主ギャップ長 10〜30 $\mathrm{mm} の$ 実験結果 ${ }^{(2)(3)}$ を考慮すれば，小形 GISに坊け る破壊は, 基本的には本研究で得られた破壊過程と類 似した破壊過程をとるものと推察される。従って，本 研究結果は，その破壊機構の解明に十分適用できるも のと思われる。更に, 大形実用器への適用性について は, 今後の研究に待ちたい。

\section{5. まとめ}

$\mathrm{SF}_{6}$ ガス中アークを伴うギャップの破壊電压は，ア 一クによって大幅に低下することを述べ，その破壊機 構を明らかにした。得られた結果を要約すると次のよ うである。

（1） $\mathrm{SF}_{6}$ ガス中において，アークを伴ったギャッ プの破壊電圧は, アーク点弧直後に低下する初期特 性, 点弧数分後に現れる上昇域, ほほ一定值を保つ I 領域，再び低下を始める低下域，および低下後のII領 域の特性域に分けられる。

(2) 活性アルミナ $\left(\mathrm{Al}_{2} \mathrm{O}_{3}\right)$ を夷験容器内へ入れる と，I領域の破壊電圧は上昇した。これは,アークに よる分解ガスが $\mathrm{Al}_{2} \mathrm{O}_{3}$ に吸収されるためと結論さ れた。 
（3）コンピュータによる気流解析から，ディスク を下側へ配置した場合でも，アークに起因した上昇気 流の存在が認められた。

（4）アークに起因して電極表面へ付着する化合物 の X 線解析から,アークを継続させるとイオウ化合 物とフッ素化合物が生成付着することが明らかになっ た。また, この付着物によって破壊電圧が上昇するこ とも明らかになった。

（5） 圧力の低下は，アーク径の増大をもたらし， 初期特性の短縮, つまり破壊電圧の上昇を促進し, ア ーク点弧後の異常低下から上昇までの時間を速める作 用がある。また同じ圧力ならば，アーク電極の大きさ (半径)を減少させた場合にも同様な特性が得られる。

（6）アークを伴ったギャップの破壊電圧低下の機 構を明らかにし，破壊の模式図を提案した。

最後に, 本研究の遂行にあたり, 有益な御指導と御 べんたつをいただいた名古屋大学工学部鬼頭幸生教 授, 九州大学客員教授宅間 董博士, ならびに中部 電力(株)工務部次長向山 翼氏, 同工務技術課課長 小林重之氏，同工務技術課主任高木 勲氏に深甚の 謝意を表します。

なお, 本研究は, 中部電力(株)「GIS 異常予知技術 の開発研究」の一環として行われたものであることを 付記し，関係各諸氏に謝意を表します。

(平成 2 年 5 月 9 日受付)

\section{文献}

（1）紐川・関谷，他：「SF 6 中微小放電を伴ったギャップの絶緑破 壊」, 電気学会開閉保護装置研資, SPD-89-14 (平元)

（2）関谷・細川, 他：「SF 5 ガス中における接触不良部発弧の絶粶 低下に及ほす影響」、電学論 B, 110, 818(平 2-10)

（3）杉山・森田, 他：「SF の気流解析による唡討」, 同上 $\mathrm{B}, 110,827$ (平 2-10)

(4) T. E. Broadbent \& J. K. Wood: "A thermally triggered spark gap", Brit. J. Appl. Phys., 6, 368(1955)

(5) A. M. Sletten \& T. J. Lewis: "Characteristics of the trigatron spark-gap", Proc. Instn. Elect. Engrs, 104C, 54 (1957)

(6) T. E. Broadbent: "The breakdown mechanism of certain triggered spark gaps", Br. J. Appl. Phys., 8, 37(1957)

(7) J. D. Cobine: Gaseous Conductors, p. 393 (1958)Dover Pub. lications, Inc.

(8) T. E. Broadbent \& A. H. A. Shlash: "The development of the discharge in the trigatron spark gap at very high voltage", Br.J. Appl. Phys., 14, 687(1963)

(9) T. Ishikawa: "Effect of the Plasma-Jet in a Doubl Elec trode Spark Gap", J. Phys. Soc. Japan, 19, 367 (1964)

(10) E. Kuffel \& M. M. Bera: "Breakdown in Triggered Spark Gaps in Air", IEEE Trans. Power Apparatus. Syst., PAS87,1628 (1968)

(11) 栗本・練川・三好：「補助放電による気中ギャップの放電破 壊」, 電学論 A, 93, 199 (昭 48-5)

（12）広岡・桑原他：「SF $\mathrm{S}_{6}$ ガスの大電流アークに上る分解生成物 と穴の反応機構」, 同上 A, 95, 483(昭 50-11)

（13）潮・宮本・鎌谷「放電における $\mathrm{SF}_{6}$ ガスの化学的特性」, 三菱 電機技報, 36, 1360 (昭 37)
(14) S. Tominaga, H. Kuwahara \& K. Hirooka: "Influence of arc-decomposed $\mathrm{SF}_{6}$ gas on cast epoxy insulators for gas insulated switchgears", IEEE Trans. Power Apparatus Syst., PAS-98, 2107 (1979)

（15）湯本・飯田・堺：「SF $F_{6}$ ガス分解生成物の生成過程と絶縁破壤 に及ほす影響」, 電学論 A, 105, 437 (昭 60-8)

(16) T. Suzuki, H. Yoshida, A. Koyama \& S. Tomimuro: Degradation process of grease due to $\mathrm{SF}_{6}$ gas dissociation products", IEEE Trans. Power Apparatus Syst., PAS-101, 2805(1982)

(17) R. J. Van Brunt: "Production Rates for Oxy-fluorides $\mathrm{SOF}_{2}, \mathrm{SO}_{2} \mathrm{~F}_{2}$, and $\mathrm{SOF}_{4}$ in $\mathrm{SF}_{6}$ Corona Discharges", J. Res. Nat. Bur. Stand., 90, 229(1985)

(18) T. Suzuki, S. Nakayama \& T. Yoshimitsu: "Degradation of insulating materials, including $\mathrm{SiO}_{2}$ due to $\mathrm{SF}_{6}$ gas dissociation products", IEEE Trans. Elect. Insulation., EI $-15,53(1980)$

(19) I. Sauers, H. W. Ellis \& L. G. Christophorou: "Neutral decoposition products in spark breakdown of $\mathrm{SF}_{6}$ ", ibid., EI-21, 111 (1986)

（20）室岡・K. R. Hearne：「絶縁破壊電圧に及ぼす電極温度の影 響」, 電学論 A, 92, 423(昭 47-9)

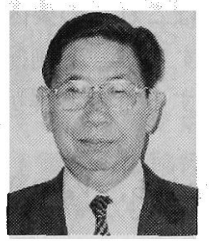

細川辰 三（正員）

昭和 2 年 9 月 19 日生。 29 年 3 月 東京電機大学電気工学科卒業。35 年 5 月名古屋工業大学電気工学科勤 務。同技官，助手，講師，助教授を 経て, 59 年 4 月同教授。60 年 4 月学科改組により電 気情報工学科教授, 現在に至る。工学博士。主とし て, 気体中放電破壊の研究に従事。日本物理学会, 電 気加工学会, プラズマ・核融合学会会員。

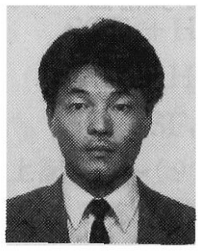

\section{河 村 和 彦（正員）}

昭和 41 年 2 月 9 日生。平成 2 年 3 月名古屋工業大学大学院工学研究 科博士前期課程修了。同年中部電力 (株) 入社。同社電気利用技術研究所 にて産業加熱の研究に従事し, 現在に至る。

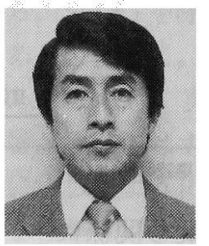

\section{関 谷昌 久 (正員)}

昭和 22 年 1 月 1 日生。 44 年 3 月 大同工業大学電気工学科卒業。 44 年 4 月同大学技手, 45 年 4 月同助 手, 59 年 4 月同講師, 平成元年 4 月同助教授, 現在に至る。工学博士。主として, 気体 放電現象, 特に, 負コロナ放電現象の研究に従事。静 電気学会, プラズマ・核融合学会, 日本アイソトープ 協会会員。 


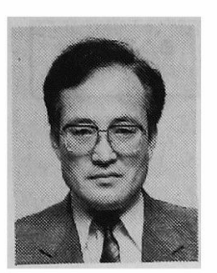

森田公 (正員)

昭和 15 年 12 月 19 日生。 38 年 3 月名古屋工業大学電気科卒業。同年 4 月富士電機(株) 入社。55 年 4 月 (株) 富士電機総合研究所出向。高電 圧開閉保護装置の開発, 遮断現象, 高電圧絶縁現象の 研究などに従事し, 現在に至る。工学博士。IEEE 会 員。

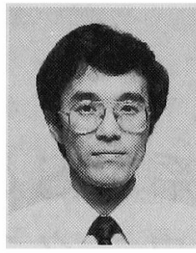

杉山修 - (正員)

昭和 31 年 1 月 22 日生。 54 年 3 月東京工業大学工学部電気電子工学 科卒業。同年 4 月富士電機 (株) 入 社。55 年 4 月(株)富士電機総合研 究所出向。高電圧開閉保護装置の開発, 遮断現象の研 究などに従事し, 現在に至る。 